\title{
Can agriculture support climate change adaptation, greenhouse gas mitigation and rural livelihoods? insights from Kenya
}

\author{
Elizabeth Bryan • Claudia Ringler • Barrack Okoba • \\ Jawoo Koo • Mario Herrero • Silvia Silvestri
}

Received: 10 February 2012 / Accepted: 11 November 2012 / Published online: 5 December 2012

(C) The Author(s) 2012. This article is published with open access at Springerlink.com

\begin{abstract}
Changes in the agriculture sector are essential to mitigate and adapt to climate change, meet growing food demands, and improve the livelihoods of poor smallholder producers. What agricultural strategies are needed to meet these challenges? To what extent are there synergies among these strategies? This paper examines these issues for smallholder producers in Kenya across several agroecological zones. Several practices emerge as triple wins, supporting climate adaptation, greenhouse gas mitigation, and profitability goals. In particular, integrated soil fertility management and improved livestock feeding are shown to provide multiple benefits across all agroecological zones examined. Triple wins of other agricultural practices are limited to specific agroecological zones. Irrigation and soil and water conservation, for example, are essential for adaptation, mitigation, and profitability in arid areas. The results suggest that agricultural investments targeted toward these triple-win strategies will have the greatest payoff in terms of increased resilience of farm and pastoralist households and global climate change mitigation. To reap the benefits of triple-win strategies will require that policymakers, researchers, and practitioners move away from isolated approaches focused on either adaptation or mitigation or rural income generation toward a more holistic assessment of joint strategies as well as their tradeoffs and synergies.
\end{abstract}

Electronic supplementary material The online version of this article (doi:10.1007/s10584-012-0640-0) contains supplementary material, which is available to authorized users.

E. Bryan $(\bowtie) \cdot$ C. Ringler $\cdot$ J. Koo

International Food Policy Research Institute,

2033 K Street NW, Washington, DC, 20006, USA

e-mail: e.bryan@cgiar.org

B. Okoba

Kenya Agricultural Research Institute-Kabete, PO Box 14733-00800, Waiyaki Way, Nairobi, Kenya

M. Herrero $\cdot$ S. Silvestri

International Livestock Research Institute, P.O. Box 30709, Nairobi 00100, Kenya 


\section{Introduction and background}

The international community faces great challenges in the coming decades including reining in global climate change, meeting growing food demands, and promoting sustainable development. Changes in the agriculture sector are essential for meeting all of these challenges. Agriculture provides the main source of livelihood for the poor in developing countries, and improving agricultural productivity and increasing profits from agricultural production are critical to achieving food security as well as most of the targets specified under the Millennium Development Goals (Rosegrant et al. 2006). Agriculture also contributes a significant share (9\%) of greenhouse gas (GHG) emissions, more if related land-use change (particularly deforestation), and livestock are included (CAIT 2010). At the same time, long-term changes in average temperatures, precipitation, and increased climate variability threaten agricultural production, food security, and the livelihoods of the poor (Adger et al. 2003). While mitigation of GHG emissions can lessen the extent of climate change, adaptation is essential to reduce the impact of climate change on food security and to protect the livelihoods of poor farmers.

Characteristic of much of Sub-Saharan Africa, Kenya is highly vulnerable to climate change (Herrero et al. 2010a). The country remains dependent on rainfed agriculture, adoption of modern technology is low, poverty remains widespread, and infrastructure and markets are under-developed (Nyoro et al. 2001; Odhiambo et al. 2004; Kristjanson et al. 2009). Kenya already experiences high temperatures and climate models suggest that the median temperature increase for the region will be significantly higher than the global average (Hulme et al. 2001; Christensen et al. 2007). However, there is much less confidence about future changes in rainfall in the region. While most global models project small increases in average precipitation in East Africa (Christensen et al. 2007), these may be offset by Indian ocean warming, greater rainfall variability, and an increase in the frequency of extreme events (Hulme et al. 2001; Funk et al. 2008). Regional variations in precipitation are large; the coastal region and lowlands will likely become drier while the Kenyan highlands and Northern Kenya are expected to become wetter (Thornton et al. 2006). Moreover, despite potential increases in average rainfall, Kenya is expected to experience declines in the production of key staples, such as maize and wheat, due to increased evapotranspiration (Herrero et al. 2010a).

In this context, adaptation to increase the resilience of poor farmers to the threat of climate change should be a priority. Adaptation can also provide co-benefits in terms of agricultural mitigation and increased productivity (FAO 2009). The literature suggests that sustainable land management (SLM) practices such as conservation tillage, cover cropping, improved livestock practices, water harvesting, agroforestry, and enhanced water and nutrient management can improve soil carbon sequestration (SCS), increase yields, and enhance resilience to climate change (Lal 2004; FAO 2009; Niggli et al. 2009; Thornton and Herrero 2010). There may also be tradeoffs between increasing farm productivity and profitability, adaptation to climate change, and mitigation of GHGs.

This paper examines the extent to which there are synergies between agricultural productivity, climate change adaptation, and GHG mitigation, and highlights where tradeoffs exist for arid, semiarid, temperate, and humid areas in Kenya based on land and livestock management practices as well as adaptation strategies currently employed by farmers. Such an analysis can help policymakers identify the management practices that are available and effective in achieving these multiple objectives for different agroecological zones (AEZs) in Kenya and beyond. 


\section{Methodology}

\subsection{Data collection}

To identify and assess ongoing and alternative household-level and collective ${ }^{1}$ adaptation strategies and land management practices, 710 farm households were interviewed by IFPRI and KARI from July 2009 to February 2010 in 13 divisions within 7 districts in Kenya (see Table 1). The study sites were selected to cover communities where agricultural mitigation and adaptation projects were operating. The survey also included suitable control sites identified using propensity score matching based on average elevation, NDVI (average 1981-2007), length of the growing period, average rainfall, area, percent of individuals below the poverty line, population in 1999, and livestock units per capita. Sites covered all major agroecological zones (AEZ) in the country except the coastal area. Participants were selected randomly from the list of community members provided by village leaders. Because of the selection approach, households interviewed are not representative of the AEZ but can be considered as case studies within each AEZ.

\subsection{Analytical methods}

Descriptive analyses of the land management practices, livestock feedings practices, and adaptation strategies reported by farmers were conducted and used as inputs into crop and livestock simulation models to analyze the synergies between adaptation and mitigation.

A crop system simulation model was used to estimate the potential dynamic changes of crop yields and the soil carbon pools under different management practices under both a dry and wet future climate for maize, the key staple crop. The CERESMaize model of the Decision Support System for Agrotechnology Transfer (DSSAT) (Jones et al. 2003; Hoogenboom et al. 2011) with the integrated CENTURY Soil Organic Model (Parton et al. 1987; Gijsman et al. 2002) was used to examine variations of seven management practices or "packages" (two variety choices, fertilizer application, manure application, residue management, rotation with beans, soil and water conservation (SWC) techniques, and supplementary irrigation) and two sets of climate projections out to 2050 (CSIRO-Mk3.0 and MIROC3.2 to represent a possible dry and wet future climate, respectively, with the SRES A2 scenario) for each district. Appendix A provides details on the methodology, evaluation of the model, and limitations of the modeling approach.

The potential impacts of improved feeding practices on the productivity and methane emissions of cattle were examined using a ruminant simulation model housed at the International Livestock Research Institute. The model predicts feed intake, productivity, manure production, and methane emissions of ruminants (Herrero et al. 2002). Current and alternative cattle diets were constructed using the main feeds reported in the household survey in quantities devised to match reported dairy production and the main feed ingredients that have been increasing in the seven districts based on survey results, respectively. This model has been previously used to estimate productivity and methane emissions of African domestic ruminants and methane emission factors for the Intergovernmental Panel on Climate Change (Herrero et al. 2008; Thornton and Herrero 2010).

\footnotetext{
${ }^{1}$ Data from the community-based module were not used for this assessment.
} 
Table 1 Study sites

\begin{tabular}{lll}
\hline District & Agroecological zone & No. of households \\
\hline Garissa & Arid & 134 \\
Mbeere South & Semi Arid & 97 \\
Njoro & Semi Arid & 104 \\
Mukurwe-ini & Temperate & 95 \\
Othaya & Temperate & 88 \\
Gem & Humid & 96 \\
Siaya & Humid & 96 \\
Total & & 710 \\
\hline
\end{tabular}

Source: Authors

To examine the profitability of different management strategies, data on changes in soil carbon, yield, and livestock productivity from the crop and livestock simulation models were combined with information on costs of production from the field survey and expert opinion to calculate net profits for particular sets of management practices compared with a baseline case of no management. Based on these analyses triple-win strategies were identified.

\section{Agricultural management practices and climate change adaptation strategies}

\subsection{Common land management practices}

In order to assess the impact of land management practices on farm production, farmers were asked what management practices they were using on cropland and why they chose to adopt those practices, regardless of whether they were adopted as an adaptation strategy. Farmers provided a wide range of responses. The most common practices employed by farmers included inorganic fertilizer (45\%), composting or manure (40\%), intercropping (39\%), soil bunds $(18 \%)$, residues $(12 \%)$, and grass strips $(12 \%)$. Common reasons provided by farmers for adopting new management practices included increasing productivity, reducing erosion, increasing soil fertility, and increasing the water-holding capacity of the soil.

\subsection{Livestock feeding practices}

Households owning livestock were asked about the types of feeds used during different times of the year. Short-distance rangelands are the primary source of feed during the dry and wet seasons, while maize stover, roadside weeds, and cut-and-carry fodders represent other important sources of livestock feed. They also reported on changes in feed resource availability over the last 10 years as a result of drought, climate change, and land use change. Over this timeframe, some feed resources became unavailable, such as kikuyu grass; while new sources have become available, including napier grass (Pennisetum purpureum), desmodium (Desmodium intortum), mathenge (Prosopis juliflora), and calliandra (Calliandra spp.).

\subsection{Adaptive responses to perceived climate change}

Surveyed farmers adopted a range of practices in response to perceived climate change. Farmers' adaptation strategies were ascertained through open-ended questions about actions 
undertaken to counteract perceived long-term (over 20 years) changes in temperature and rainfall, following the approach of earlier microeconomic climate change adaptation studies (Bryan et al. 2009; Deressa et al. 2009). The most common responses included changing crop variety (33\%), changing planting dates (20\%), and changing crop type (18\%). Other responses included planting trees $(9 \%)$, reducing livestock numbers $(7 \%)$, diversifying, changing, or supplementing livestock feeds (7\%), changing fertilizer application (7\%), and SWC (5\%).

\section{Simulation of the impact of cropland management practices on maize yields and soil carbon sequestration}

The crop simulation model results for alternative adaptation strategies showed considerable variation in maize yield and soil carbon sequestration across the various technology packages, and AEZ and soil combinations. Results for a selected set of management packages are shown in Appendix A. Overall, the simulated results show that the best set of management practices or "packages" for SCS and yield improvement would generally include integrated soil fertility management, although the optimal combination of nutrient inputs (manure, inorganic fertilizer, and crop residues) depends on a number of factors, including crop type, soil type, and AEZ. Importantly, inorganic fertilizer applications alone do not enhance SCS but must be combined with other soil fertility management practices (manure application, mulching, residue management, or a combination of these).

Similarly, residue management (for example, leaving $50 \%$ of crop residues on the field after harvest) shows high potential for SCS across districts, reflecting the positive role of residues for replenishing soil nutrients and increasing biomass production in the following season. Only in a small number of locations was full removal of residues necessary for SCS, including in the arid site under a drier future. In this case, limited soil moisture might hinder microbial activities and the decomposition of organic matter.

The results regarding water management differ significantly by AEZ. In the arid, pastoralist site, maize yields under rainfed conditions are very low due to limited water availability and climate variability, and irrigation is essential to achieve reasonable yield levels. Yields are maximized when SWC and irrigation are combined. The humid sites benefit from relatively high rainfall and low variability, while nitrogen is limited. As a result, the effects of SWC techniques are limited, and irrigation in fact lowers average yield levels across simulated packages, possibly due to increased leaching of nitrogen from the soil. In the semiarid and temperate sites, where water is somewhat limited, SWC practices and irrigation increase yield levels. However, yield improvements are much larger from soil nutrient inputs (fertilizer and manure). Thus, while the use of SWC and irrigation was strongly favored in the arid site, soil nutrient management was more important in the temperate, semi-arid and humid sites.

Rotation of maize with beans was shown to enhance SCS and yield in only a few cases. While rotation with beans is generally positive for SCS, these benefits are limited compared with more explicit nitrogen input measures. Moreover, use of a hybrid variety did not increase soil carbon, even with nutrient management practices in most AEZs. This may be because the hybrid varieties used were not specifically calibrated for each local condition due to a lack of phenological data. Finally, results differ only slightly across future climate scenarios. This is likely due to the fact that, despite large 
differences between these scenarios at the global level, climate predictions are somewhat similar for Kenya.

\section{Potential impacts of improved livestock feeding as a climate change adaptation and GHG mitigation strategy}

A governmental push toward market-oriented milk production is driving production systems in the study areas toward increased use of improved feeding practices. These practices reduce the fluctuation of feed during the dry season, thereby reducing risk and helping farmers adapt to climate change (Thornton and Herrero 2010). These practices are also being promoted by several international agencies and projects (for example, the Bill \& Melinda Gates Foundation East Africa Dairy Development Programme) as a vehicle for intensifying dairy production.

\subsection{Baseline diets}

Data on the current diets of dairy cattle in the different districts from the household survey is consistent with that from other studies (Zemmelink and Romney 1999; Bebe 2003; Herrero et al. 2008) and include rangeland grazing, maize stover, cut-and-carry fodder, roadside weeds, and grain supplements with significant differences across districts.

Differences in main feed sources reflect the productive orientation and management of the systems in the various study areas. Njoro, Mukurwe-ini, and Othaya have a more commercial orientation, with stall-fed, high-grade dairy animals with good diets (reflected in high energy densities as a result of the use of concentrates), leading to high milk production. On the other hand, rangeland-based systems point toward more extensive production, where supplementation, mostly in the dry season, is based on crop residues and on the opportunistic use of feed resources like roadside weeds.

The relationship between the quality of the diet and manure and methane production follows well-established principles: higher quality diets and higher feed intake lead to greater methane production. However, methane production per unit of animal product decreases as the dietary quality improves. Therefore, supplementation with high-quality forages is both an important adaptation and GHG mitigation strategy. As expected, better diets in the more dairy-oriented districts of Njoro, Mukurwe-ini, and Othaya produced the least methane per unit of milk but also produced overall higher quantities of methane due to increased feed intakes of the animals. Cows in the drier, agropastoral regions were significantly less efficient in terms of methane produced per unit of milk (up to five times less efficient in some cases), since their diets were poorer and most of the energy was used for maintaining the animals instead of producing milk.

Manure production ranged from 657 to $730 \mathrm{~kg}$ per animal ( $250 \mathrm{~kg}$ body weight) across districts. ${ }^{2}$ This close range means that, in overall terms, differences in excretion rates were relatively small, in contrast with the more dramatic differences in milk and methane production across districts.

\footnotetext{
${ }^{2}$ This result was expected because the model was run for animals of a constant body weight, which largely controls the overall magnitude of the intake figures for that range of diet qualities (8.4 to 10.5 megajoules of metabolizable energy per kilograms of dry matter).
} 


\subsection{Testing alternative feeding scenarios}

Alternative scenarios of diet composition were tested by constructing new supplementation regimes using the feed sources reported to have appeared in the surveyed districts in the last 10 years. The simulated $250-\mathrm{kg}$ animals consumed between 4.5 and $6.0 \mathrm{~kg}$ of dry matter (DM) feed per day in the baseline diets, and the scenarios tested aimed at replacing between 15 and $50 \%$ of the baseline ration in terms of DM consumed. Scenarios assumed that new feeds would replace maize stover to enable farmers to use these residues on cropland.

On average, the supplementation strategies tested increased milk production by $36 \%$ while also increasing total manure and methane production by 6 and $4 \%$, respectively, and decreased methane production per liter of milk by $20 \%$. The impact of the new diets varied across districts.

As a general trend, the largest positive impacts of supplementation were observed in the districts with the poorest-quality baseline diets (Garissa, Gem, Mbeere, and Siaya). In these districts, milk production increased between 12 and $136 \%$ while manure and methane production changed between 0 and $16 \%$ and -5 and $16 \%$, respectively. While methane emissions increased overall in many scenarios, efficiency per liter of milk improved in every scenario. Methane production per liter of milk decreased significantly by between -8 and $-60 \%$. Thus, if simple practices and modest supplementation plans can be implemented, methane production in these regions could decline significantly. However, improved feeding practices generally will be profitable only if livestock owners have access to markets for dairy products. This is generally not the case in the more remote arid district of Garissa, where the feeding efficiency gap is largest.

Increasing milk production while reducing methane production per liter of milk was also possible in the districts with higher-quality baseline diets, but improvements were smaller ( 8 to $49 \%$ for milk production and -7 to $-21 \%$ for methane per liter of milk, respectively). In addition to the benefits from decreased methane emissions, alternative livestock feeding practices would enable farmers to apply maize stover as residues on their fields, leading to additional agricultural GHG mitigation benefits from SCS.

\section{Profitability of alternative management practices}

This section evaluates the profitability of the most promising crop and livestock management practices identified above in monetary terms to determine the extent to which these practices provide financial benefits for households in the study sites. This analysis used data on soil carbon changes and maize yields from the crop simulation model and data on milk production and methane emissions from the livestock simulation model. Costs were taken from the survey where possible, or based on expert opinion (for example, construction costs of SWC and irrigation structures) or based on retail prices for inputs (such as fertilizers). (See Appendix B for details on production costs.)

\subsection{Profitability of cropland management strategies}

An economic analysis for a select set of management packages is performed to determine whether these packages provide sufficient incentives (from increased revenues and carbon payments) to encourage adoption by farmers. In Package 1, $50 \%$ of crop residues are left on the field. In Package 2, $40 \mathrm{~kg}$ of nitrogen fertilizer per hectare and $3 \mathrm{t}$ of manure per hectare are also added. Package 3 adds SWC practices and rotation with legumes every fourth 
year. Package 4 includes all practices in package 3 plus irrigation $(100 \mathrm{~mm}$ per hectare of furrow irrigation).

The change in annual net revenues $(\Delta N R)$ after adopting a particular management package $(s)$, compared to a baseline without improved practices $(i)$, is calculated as:

$$
\Delta N R(i, s)=\left[\Delta Y(i, s) \times P_{m}-\left(\Delta L(i, s) * w+\Delta I(s) * p_{i}+M(s)+\Delta R(s) * p_{n}\right)+\Delta C(s) * P_{c}\right]
$$

for each AEZ-soil type combination. $\Delta Y(i, s)$ is the change in maize yield after adopting one of the management packages and $P_{m}$ is the price per $\mathrm{kg}$ of maize. $\Delta L(i, s)$ represents the change in labor effort (in person days per hectare per year) from switching to an improved package, and $w$ is the wage rate. $\Delta I(s)^{*} p_{i}$ represents the increase in the cost of inputs of fertilizer and manure ${ }^{3}$ for management packages 2,3 , and $4 . M(s)$ is the annual cost of construction, operation and maintenance of soil and water conservation and irrigation structures in packages 3 and 4 .

In many parts of Kenya, where maize stover is an important source of livestock feed, there is a tradeoff with livestock production when residues are left on the field (Thorne et al. 2002). Therefore, $\Delta R(s)^{*} p_{n}$ captures the cost of purchasing replacement feed for livestock (napier grass) following the application of residues on cropland.

$\Delta C(s)^{*} P_{c}$ is the payment that farmers could receive per hectare at a price $P_{c}$ per ton of carbon sequestered per period. A price of $\$ 10$ per ton of $\mathrm{CO}_{2} \mathrm{e}-$ reflecting the average offset price for CER contracts under the CDM in 2011 (Kossoy and Guigon 2012) - is assumed in order to calculate potential profits from linkage with carbon markets.

All alternative packages increase SCS and most packages also increase net revenue from maize production compared with a strategy of no improvement (Table 2). The exceptions are Packages 1 and 2 in arid areas with clayey soil and Package 2 in arid areas with sandy soil. In these scenarios, the cost of replacement feed and other inputs outweighs the benefits from increased productivity.

The increase in net profits from maize production is highest under Packages 2, 3 and 4 in the semiarid, humid, and temperate areas. In these AEZs, the biggest increase in net profits results from the application of inorganic fertilizer and manure (Package 2), with modest additional profits gained from the addition of SWC and rotation (Package 3) and, in some cases, irrigation (Package 4). The increase in net profits is also high in arid areas under Package 4, which includes irrigation, and modest gains are shown under Package 3, which includes SWC.

Potential revenues from the increase in SCS are minimal when only $50 \%$ of crop residues are left on maize fields (Package 1). However, revenues rise to between $\$ 2$ and $\$ 10$ per ha depending on the management package, AEZ and soil type combination.

Leaving crop residues on the field has a high potential for both yield improvement and SCS. However, in the rangeland-based systems, where residues are used as a feed supplement during the dry season, farmers may not always choose to leave residues in the field. To further explore the opportunity cost of using crop residues on cropland, we considered a set of management packages that include the application of $75 \%$ of residues on cropland, leaving only $25 \%$ of residues for feed (Packages 5-8, results shown in Appendix C).

With $75 \%$ residue retention, revenues from SCS tend to increase slightly compared to packages with only $50 \%$ residues. However, in more than half of the AEZ-soil type

\footnotetext{
${ }^{3}$ Although manure is not generally purchased as an input, the amount of manure assumed in these management packages (three tons per hectare) is more than can realistically be produced on an average Kenyan farm.
} 
Table 2 40-year average annual incremental revenues from SOC and maize yield

\begin{tabular}{|c|c|c|c|c|c|c|c|c|c|}
\hline \multirow[b]{3}{*}{ AEZ } & \multirow[b]{3}{*}{ Soil } & \multicolumn{2}{|c|}{ Package 1} & \multirow{2}{*}{\multicolumn{2}{|c|}{$\begin{array}{l}\text { Package } 2 \\
\text { RSD50, FRT, } \\
\& \text { MNR }\end{array}$}} & \multirow{2}{*}{\multicolumn{2}{|c|}{$\begin{array}{l}\text { Package } 3 \\
\text { RSD50, FRT, MNR, } \\
\text { SWC, \& ROT }\end{array}$}} & \multirow{2}{*}{\multicolumn{2}{|c|}{$\begin{array}{l}\text { Package } 4 \\
\text { RSD50, FRT, MNR, } \\
\text { SWC, ROT, \& IRG }\end{array}$}} \\
\hline & & \multicolumn{2}{|l|}{ RSD50 } & & & & & & \\
\hline & & $\begin{array}{l}\text { Revenue } \\
\text { from } \\
\text { carbon } \\
\text { (US\$/ha) }\end{array}$ & $\begin{array}{l}\text { Net } \\
\text { revenue } \\
\text { from } \\
\text { yield } \\
\text { (US\$/ha) }\end{array}$ & $\begin{array}{l}\text { Revenue } \\
\text { from } \\
\text { carbon } \\
\text { (US\$/ha) }\end{array}$ & $\begin{array}{l}\text { Net } \\
\text { revenue } \\
\text { from } \\
\text { yield } \\
\text { (US\$/ha) }\end{array}$ & $\begin{array}{l}\text { Revenue } \\
\text { from } \\
\text { carbon } \\
\text { (US\$/ha) }\end{array}$ & $\begin{array}{l}\text { Net } \\
\text { revenue } \\
\text { from } \\
\text { yield } \\
\text { (US\$/ha) }\end{array}$ & $\begin{array}{l}\text { Revenue } \\
\text { from } \\
\text { carbon } \\
\text { (US\$/ha) }\end{array}$ & $\begin{array}{l}\text { Net } \\
\text { revenue } \\
\text { from } \\
\text { yield } \\
\text { (US\$/ha) }\end{array}$ \\
\hline Arid & Clay & 0 & -16 & 2 & -195 & 5 & 7 & 5 & 1,151 \\
\hline Arid & Sand & 1 & 35 & 4 & -221 & 6 & 241 & 10 & 892 \\
\hline Semiarid & Loam & 1 & 177 & 10 & 910 & 9 & 1,072 & 5 & 1,023 \\
\hline Semiarid & Sand & 1 & 116 & 4 & 231 & 6 & 309 & 6 & 162 \\
\hline Semiarid & Clay & 1 & 210 & 7 & 1,626 & 7 & 1,920 & 6 & 1,947 \\
\hline Temperate & Loam & 1 & 12 & 10 & 816 & 10 & 910 & 9 & 736 \\
\hline Humid & Loam & 0 & 116 & 4 & 1,431 & 4 & 1,513 & 4 & 1,061 \\
\hline
\end{tabular}

Source: Authors

Notes: RSD50 $=50 \%$ of residues left in field; FRT $=$ fertilizer; $\mathrm{MNR}=$ manure; $\mathrm{SWC}=$ soil and water conservation; ROT=rotation with dry beans; $I R G=$ irrigation

combinations, the use of $75 \%$ of residues as opposed to $50 \%$ does not increase maize yield (and profits) enough to make up for the cost of purchasing additional replacement feed. This shows that the optimal allocation of residues to crops and livestock feed in terms of profitability depends on the particular combination of management practices and agroecological and soil conditions, and the value of livestock and its products.

The results also show that the greatest benefits to smallholders come from increases in productivity, rather than agricultural mitigation. At \$1-12 per hectare, potential payments for carbon offsets are very small, but not insignificant for the ultra-poor. Rather than providing direct payments to farmers, the revenues from linking smallholder farmers to carbon markets could be used to cover some of the costs of the overall project, such as extension services, or for investments in community infrastructure (e.g. Lager and Nyberg 2012).

\subsection{Profitability of improved livestock feeding}

To analyze the profitability of the various feeding management strategies, we calculated the cost of emissions for the different scenarios to determine which of the alternative feeding strategies reduces emissions. Table 3 illustrates the cost of $\mathrm{CO}_{2}$-equivalent emissions for alternative feeding strategies compared to the baseline; alternatives that lead to a reduction in emissions are shown in bold. Total methane emissions were reduced in only 4 out of 14 alternative feeding scenarios due to improved feeding practices, but methane emissions per liter of milk are always lower.

Table 3 also shows the results from the profitability analysis for milk production in the seven districts for alternative feeding strategies. Feeding scenarios with increased profitability per liter of milk compared to the baseline are in bold. In most cases, alternative feeding practices increase productivity and net profits per liter of milk. One exception is Garissa, where the cost of purchasing improved feeds reduces net profits per liter of milk (although 
Table 3 Cost of carbon emissions and profitability of milk production in the seven districts based on alternative feeding strategies

\begin{tabular}{|c|c|c|c|c|c|c|c|}
\hline \multirow[b]{2}{*}{ District } & \multicolumn{3}{|c|}{ Baseline diet } & \multicolumn{4}{|c|}{ Improved feeding } \\
\hline & $\begin{array}{l}\text { Cost of } \\
\mathrm{CO}_{2} \mathrm{e} \\
\text { emissions } \\
\text { (US\$) }\end{array}$ & $\begin{array}{l}\text { Baseline } \\
\text { net } \\
\text { revenues } \\
\text { (US\$) }\end{array}$ & $\begin{array}{l}\text { Baseline net } \\
\text { revenues per } \\
\text { liter of milk } \\
\text { (US\$) }\end{array}$ & Scenario & $\begin{array}{l}\text { Cost of } \\
\mathrm{CO}_{2} \mathrm{e} \\
\text { emissions } \\
\text { (US\$) }\end{array}$ & $\begin{array}{l}\text { Net revenues } \\
\text { with improved } \\
\text { feed (US\$) }\end{array}$ & $\begin{array}{l}\text { Net revenues } \\
\text { per liter of } \\
\text { milk with } \\
\text { improved } \\
\text { feed (US\$) }\end{array}$ \\
\hline \multirow{4}{*}{ Garissa } & \multicolumn{7}{|c|}{ Prosopis } \\
\hline & 6.53 & 92.1 & 0.33 & $1.5 \mathrm{~kg}$ & 6.45 & 104.1 & 0.23 \\
\hline & 6.53 & 92.1 & 0.33 & $3 \mathrm{~kg}$ & 6.16 & 118.8 & 0.18 \\
\hline & & & & Desmodil & & & \\
\hline \multirow{3}{*}{ Gem } & 7.77 & 62.2 & 0.11 & $1 \mathrm{~kg}$ & 7.52 & 172.3 & 0.26 \\
\hline & 7.77 & 62.2 & 0.11 & $2 \mathrm{~kg}$ & 7.85 & 169.2 & 0.23 \\
\hline & & & & \multicolumn{4}{|c|}{ Napier grass } \\
\hline \multirow[t]{3}{*}{ Mbeere } & 9.64 & 31.3 & 0.04 & $2 \mathrm{~kg}$ & 9.94 & 150.8 & 0.16 \\
\hline & 9.64 & 31.3 & 0.04 & $3 \mathrm{~kg}$ & 9.90 & 146.2 & 0.15 \\
\hline & & & & Grevillea & & & \\
\hline \multirow[t]{3}{*}{ Njoro } & 9.06 & 175.8 & 0.14 & $1 \mathrm{~kg}$ & 9.61 & 279.9 & 0.19 \\
\hline & 9.06 & 175.8 & 0.14 & $2 \mathrm{~kg}$ & 10.63 & 357 & 0.19 \\
\hline & & & & \multicolumn{4}{|c|}{ Desmodium } \\
\hline \multirow[t]{3}{*}{ Mukurwe-ini } & 9.83 & 383 & 0.18 & $1 \mathrm{~kg}$ & 9.94 & 547.4 & 0.24 \\
\hline & 9.83 & 383 & 0.18 & $2 \mathrm{~kg}$ & 9.17 & 511 & 0.23 \\
\hline & & & & Hay & & & \\
\hline \multirow[t]{3}{*}{ Othaya } & 9.57 & 311.1 & 0.15 & $2 \mathrm{~kg}$ & 9.68 & 348.8 & 0.16 \\
\hline & 9.57 & 311.1 & 0.15 & $4 \mathrm{~kg}$ & 9.61 & 233.2 & 0.11 \\
\hline & & & & \multicolumn{4}{|c|}{ Napier grass } \\
\hline \multirow[t]{2}{*}{ Siaya } & 8.07 & 109.6 & 0.16 & $2 \mathrm{~kg}$ & 9.02 & 239.1 & 0.24 \\
\hline & 8.07 & 109.6 & 0.16 & $3 \mathrm{~kg}$ & 10.49 & 169.2 & 0.23 \\
\hline
\end{tabular}

Source: Authors

${ }^{\mathrm{a}}$ Assumes a carbon price of US\$10 per ton of $\mathrm{CO}_{2}$ equivalent, ${ }^{\mathrm{b}}$ Assumes a price of $\$ 0.352$ per liter of milk

total net revenues increase slightly given greater quantity of milk produced). Net profits per liter of milk also decrease compared with the baseline for the second scenario in Othaya, given the high cost of purchasing replacement feed.

\section{Abatement potential of alternative land management packages}

In order to illustrate the potential for adaptation practices to contribute to GHG mitigation on a larger scale, we extrapolate our findings on soil carbon sequestration potential and profitability to the full maize area contained within the AEZs and soil types covered by the study sites. Using a 7-class map of AEZs, we identified the maize areas for each AEZ-soil type combination covered by our study sites (representing $23 \%$ of current maize area in Kenya) (Jaetzold and Schmidt 1983; Sanchez et al. 2003; You et al. 2009). We then calculate the cumulative abatement potential for 
the selected land management packages described above assuming application to the entire maize area represented by the study sites over a 40 -year period.

Figure 1 shows the cumulative total abatement potential (in thousand tons of $\mathrm{CO}_{2} \mathrm{e}$ ) for each of the AEZ-soil type combinations found in the study sites. The set of packages shown are those with the greatest abatement potential for each particular AEZ-soil type combination. That is, the selected set of packages maximizes GHG mitigation in these areas with a cumulative abatement potential of almost 12.8 million tons of $\mathrm{CO}_{2} \mathrm{e}$ over a 40-year period. As shown, all AEZ-soil type combinations show significant abatement potential with the exception of semiarid areas with sandy soil. The greatest mitigation potential is found in the semiarid AEZ on loamy soil (4.5 million tons of $\mathrm{CO}_{2} \mathrm{e}$ ), followed by the temperate $\mathrm{AEZ}$ on loamy soil (3 million tons of $\left.\mathrm{CO}_{2} \mathrm{e}\right)$.

The $y$ axis in the figure displays the cost of implementation of each of these packages ( $\$$ per ton of $\mathrm{CO}_{2} \mathrm{e}$ ) in the given AEZ-soil type combination. The figure shows that the application of these packages provides farmers with net profits, with the greatest profits being in the humid AEZ on loamy soil (at $\$ 78$ per ton) and the least profits in the semiarid AEZ on sandy soil.

A similar analysis was done by selecting the set of packages that provide the greatest net profits in all the AEZ-soil type combinations, rather than the packages that maximize abatement potential. Under this scenario, the cumulative abatement potential is considerably lower, at 7.8 million tons of $\mathrm{CO}_{2} \mathrm{e}$ over a 40 -year period, suggesting that there is some tradeoff between mitigation and profitability.

While this analysis illustrates the potential benefits and tradeoffs of triple-win strategies on a larger scale, it is limited by the fact that the survey was not designed to be representative of the AEZs of the selected sites. Additional research would be needed to test the external validity of these results.

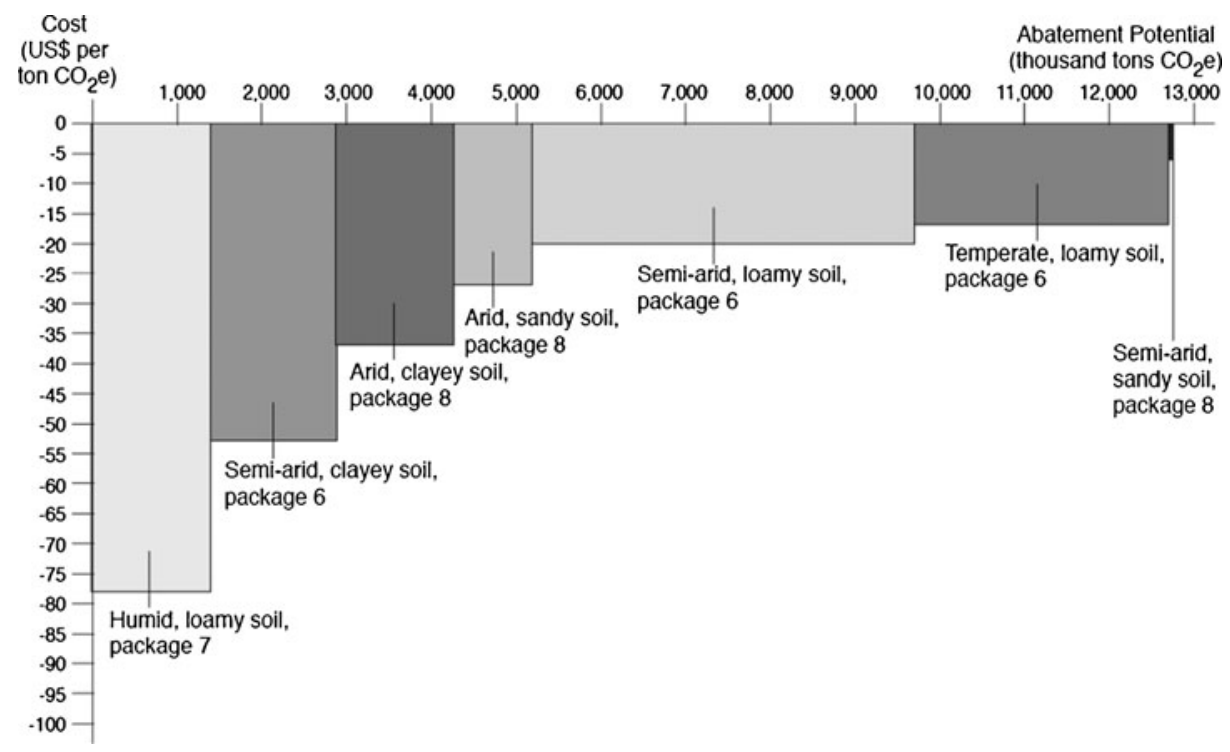

Fig. 1 Greenhouse gas abatement cost curve for agriculture in Kenya (packages with greatest abatement potential). Source: Authors 


\section{Conclusions and policy implications}

Increasing poverty, dependence on low-input agricultural production, and rapid population growth are critical challenges facing Kenya. Climate change will further exacerbate these problems unless investments in agriculture and rural development increase, particularly those targeted towards strategies that provide multiple benefits to the most vulnerable smallholder producers.

This study identifies several agricultural management strategies that provide benefits in terms of agricultural adaptation to climate change, GHG mitigation, and increased productivity and profitability for smallholder producers in Kenya. Enhanced soil nutrient management (combinations of inorganic fertilizer, mulching, and manure) emerged as a key winwin-win strategy in the Kenyan context. This strategy increases SCS, boosts yields and increases farm revenues, providing a buffer against the negative impacts of climate change. The benefits in terms of yield improvements far outweigh the costs of purchasing and applying fertilizers and manure in the study sites. This strategy is likely to offer similar benefits in other contexts in sub-Saharan Africa where fertilizer application rates are low (González-Estrada et al. 2008).

Improved feeding practices, another key win-win-win strategy, are shown to increase the productivity of dairy cattle and net profits from the sale of milk in most cases, while reducing methane emissions per liter of milk produced. In cases where improved feeding practices are not profitable, households may require additional incentives to facilitate adoption. While, in general, improved feeding practices result in an increase in overall methane emissions, when combined with destocking, emissions are likely to decline overall. Maintaining a smaller number of better-quality, more productive animals is a strategy advocated by a number of agencies and NGOs operating in Kenya and one that many households are already adopting in response to climate change. Such strategies may also be effective in other smallholder livestock systems in East Africa and South Asia (McDermott et al. 2010; Thornton and Herrero 2010).

To maximize the synergies and reduce the tradeoffs implicit in various land management practices affecting crop and livestock production, food security, adaptation, mitigation, and development considerations should be integrated into the country's development and climate change strategies. However, key policy documents either fail to include climate change considerations (e.g. the country's development blueprint-Kenya Vision 2030); or do not integrate adaptation and mitigation strategies (e.g. the National Climate Change Response Strategy). Transcending isolated approaches focused on either mitigation, adaptation, rural development, or food security will lead to a more explicit assessment of these sometimes competing goals and the identification of strategies that maximize the benefits to smallholder producers.

Promoting the adoption of triple-win strategies will be a major challenge. The extensive literature on constraints to the adoption of agricultural technologies and practices shows that there are several factors that impede uptake, such as lack of information, risk aversion, lack of access to input and output markets, and lack of financial incentives (Barrett et al. 2002; Ehui and Pender 2005; Lee 2005; Herrero et al. 2010b; McDermott et al. 2010). Overcoming these obstacles will require targeted investments to make smallholder systems more marketoriented (Herrero et al. 2010b; McDermott et al. 2010). Indeed, farmers in Kenya with access to input and output markets have been shown to have higher use of inputs, such as fertilizer, and greater productivity (Owuor 1999; Strasberg et al. 1999). Strengthening the quality and delivery of information services is also critical, particularly because triple-win strategies are location-specific (based on the local agroecology, climate factors, soil characteristics, livelihood systems, socio-economic conditions, etc.) as this article and many others have shown (Solano et al. 2000; Ehui and Pender 2005; Lee 2005; Kato et al. 2011; Silvestri et al. 2012). 
Given greater international attention to the challenge of climate change, policymakers should explore new financing options supporting agricultural adaptation and mitigation, including adaptation funds, mitigation funds, and credit mechanisms, to promote the use of triplewin strategies. Such investments would go a long way towards improving food security, improving livelihoods, and preparing for climate change.

Acknowledgments The project was supported by the World Bank through the Trust Fund for Environmentally \& Socially Sustainable Development (TFESSD). This research was conducted under the CGIAR Research Program on Climate Change, Agriculture, and Food Security (CCAFS).

Open Access This article is distributed under the terms of the Creative Commons Attribution License which permits any use, distribution, and reproduction in any medium, provided the original author(s) and the source are credited.

\section{References}

Adger WN, Huq S, Brown K, Conway D, Hulme M (2003) Adaptation to climate change in the developing world. Prog Dev Stud 3(3):179-195

Barrett CB, Place F, Aboud A, Brown DR (2002) The challenge of stimulating adoption of improved natural resource management practices in African agriculture. In: Barrett C, Place F, Aboud AA (eds) Natural resource management in African agriculture: understanding and improving current practices. CABI, New York

Bebe BO (2003) "Herd dynamics of smallholder dairy in the Kenyan Highlands." Doctoral Thesis, Animal Production Systems Group, Wageningen University, Wageningen, Netherlands

Bryan E, Deressa TT, Gbetibouo GA, Ringler C (2009) Adaptation to climate change in Ethiopia and South Africa: options and constraints. Environ Sci Policy 12:413-426

CAIT (Climate Analysis Indicators Tool) version 7.0. (2010) World Resources Institute, Washington, DC

Christensen JH, Hewitson B, Busuioc A, Chen A, Gao X, Held I, Jones R, Kolli RK, Kwon W-T, Laprise R, Magaña Rueda V, Mearns L, Menéndez CG, Räisänen J, Rinke A, Sarr A, Whetton P (2007) Regional climate projections. In: Solomon S, Qin D, Manning M, Chen Z, Marquis M, Averyt KB, Tignor M, Miller HL (eds) Climate change 2007: the physical science basis. Contribution of working group I to the fourth assessment report of the intergovernmental panel on climate change. Cambridge University Press, Cambridge

Deressa TT, Hassan RM, Ringler C, Alemu T, Yesuf M (2009) Determinants of farmers' choice of adaptation methods to climate change in the Nile Basin of Ethiopia. Glob Environ Chang 19:248-255

Ehui S, Pender J (2005) Resource degradation, low agricultural productivity, and poverty in Sub-Saharan Africa: pathways out of the spiral. Agric Econ 32(s1):225-242

FAO (2009) Food security and agricultural mitigation in developing countries: options for capturing synergies. FAO, Rome

Funk C, Dettinger MD, Michaelsen JC, Verdin JP, Brown ME, Barlow M, Hoell A (2008) Warming of the Indian Ocean threatens eastern and southern African food security but could be mitigated by agricultural development. PNAS 105:11081-11086

Gijsman AJ, Hoogenboom G, Parton WJ, Kerridge PC (2002) Modifying DSSAT crop models for low-input agricultural systems using a soil organic matter-residue module from CENTURY. Agron J 94:462-474

González-Estrada E, Rodriguez LC, Walen VK, Naab JB, Koo J, Jones JW, Herrero M, Thornton PK (2008) Carbon sequestration and farm income in West Africa: identifying best management practices for smallholder agricultural systems in northern Ghana. Ecol Econ 67:492-502

Herrero M, Fawcett RH, Jessop NS (2002) Predicting intake and nutrient supply of tropical and temperate diets for ruminants using a simple dynamic model of digestion. Bioparametrics ruminant nutrition reference laboratories monograph. Institute of Ecology and Resource Management, University of Edinburgh, Edinburgh

Herrero M, Thornton PK, Kruska R, Reid RS (2008) Systems dynamics and the spatial distribution of methane emissions from African domestic ruminants to 2030. Agric Ecosyst Environ 126:122-137

Herrero M, Ringler C, van de Steeg J, Thornton P, Zhu T, Bryan E, Omolo A, Koo J, Notenbaert A (2010a) Climate variability and climate change and their impacts on Kenya's agriculture sector. International Livestock Research Institute (ILRI), Nairobi 
Herrero M, Thornton PK, Notenbaert AM, Wood S, Msangi S, Freeman HA, Bossio D, Dixon J, Peters M, van de Steeg J, Lynam J, Parthasarathy Rao P, Macmillan S, Gerard B, McDermott J, Seré C, Rosegrant M (2010b) Smart investments in sustainable food production: revisiting mixed crop-livestock systems. Science 327:822-825

Hoogenboom G, Jones JW, Wilkens PW, Porter CH, Boote KJ, Hunt LA, Singh U, Lizaso JL, White JW, Uryasev O, Royce FS, Ogoshi R, Gijsman AJ, Tsuji GY, Koo J (2011) Decision support system for agrotechology transfer (DSSAT) version 4.5.1.023, University of Hawaii, Honolulu, HI

Hulme M, Doherty RM, Ngara T, New MG, Lister D (2001) African climate change: 1900-2100. Clim Res 17 (2):145-168

Jaetzold R, Schmidt H (1983) Farm management handbook of Kenya, volumes 1-3, Kenya Ministry of Agriculture and German Agricultural Team of GTZ

Jones JW, Hoogenboom G, Porter CH, Boote KJ, Batchelor WD, Hunt LA, Wilkens PW, Singh U, Gijsman AJ, Ritchie JT (2003) The DSSAT cropping system model. Eur J Agron 18:235-265

Kato E, Ringler C, Yesuf M, Bryan E (2011) Soil and water conservation technologies: a buffer against production risk in the face of climate change? insights from the Nile Basin in Ethiopia. Agric Econ 42:593-604

Kossoy A, Guigon P (2012) State and trends of the carbon market 2012. World Bank, Washington

Kristjanson P, Mango N, Krishna A, Radeny M, Johnson N (2009) Understanding poverty dynamics in Kenya. J Int Dev, published online: http://onlinelibrary.wiley.com/doi/10.1002/jid.1598/pdf

Lager B, Nyberg Y (2012) How to make carbon finance work for smallholders in Africa: experience from the Kenya agricultural carbon project. In: Wollenberg E, Nihart A, Tapio-Bistrom M-L, Grieg-Gran M (eds) Climate change mitigation and agriculture. Earthscan

Lal R (2004) Soil carbon sequestration impacts on global climate change and food security. Science 304:1623-1627

Lee DR (2005) Agricultural sustainability and technology adoption: issues and policies for developing countries. Am J Agric Econ 87(5):1325-1334

McDermott JJ, Staal SJ, Freeman HA, Herrero M, Van de Steeg JA (2010) Sustaining intensification of smallholder livestock systems in the tropics. Livest Sci 130:95-109

Niggli U, Fliefibach A, Hepperly P, Scialabba N (2009) Low greenhouse gas agriculture: mitigation and adaptation potential of sustainable farming systems. FAO, Rome

Nyoro JK, Wanzala M, Awour T (2001) Increasing Kenya's agricultural competitiveness: farm level issues. Tegemeo Institute of Agricultural Policy and Development and Kenya Agricultural Research Institute, Nairobi, and Michigan State University, East Lansing

Odhiambo W, Nyangito HO, Nzuma J (2004) Sources and determinants of agricultural growth and productivity in Kenya. Discussion Paper No. 34. Kenya Institute for Public Policy Research and Analysis, Nairobi

Owuor J (1999) Determinants of agricultural productivity in Kenya. Tegemeo Institute of Agricultural Policy and Development and Kenya Agricultural Research Institute, Nairobi, and Michigan State University, East Lansing

Parton WJ, Schimel DS, Cole CV, Ojima DS (1987) Analysis of factors controlling soil organic-matter levels in great-plains grasslands. Soil Sci Soc Am J 51:1173-1179

Rosegrant MW, Ringler C, Benson T, Diao X, Resnick D, Thurlow J, Torero M et al (2006) Agriculture and achieving the millennium development goals. World Bank Report No. 32729-GLB. World Bank, Washington

Sanchez PA, Palm CA, Buol SW (2003) Fertility capability soil classification system: a tool to assess soil quality in the tropics. Geoderma 114:157-185

Silvestri S, Bryan E, Ringler C, Herrero M, Okoba B (2012) Climate change perception and adaptation of agro-pastoral communities in Kenya. Reg Environ Chang 12(4):791-802

Solano C, Bernués A, Rojas F, Joaquín N, Fernandez W, Herrero M (2000) Relationships between management intensity and structural and social variables in dairy and dual-purpose systems in Santa Cruz, Bolivia. Agric Syst 65:159-177

Strasberg PJ, Jayne TS, Yamano T, Nyoro J, Karanja D, Strauss J (1999) Effects of agricultural commercialization on food crop nput use and productivity in Kenya. MSU International Development Working Paper, 71. Michigan State University, East Lansing

Thorne PJ, Thornton PK, Kruska RL, Reynolds L, Waddington SR, Rutherford AS, Odero AN (2002) Maize as food, feed and fertilizer in intensifying crop-livestock systems in east and southern Africa: an ex ante impact assessment of technology interventions to improve smallholder welfare. ILRI Impact Assessment Series, 11

Thornton PK, Herrero M (2010) The potential for reduced methane and carbon dioxide emissions from livestock and pasture management in the tropics. Proc Natl Acad Sci 107:19667-19672

Thornton PK, Jones PG, Owiyo TM, Kruska RL, Herrero M, Kristjanson P, Notenbaert A, Bekele N, Omolo A. with contributions from Orindi V, Otiende B, Ochieng A, Bhadwal S, Anantram K, Nair S, Kumar V, 
Kulkar U (2006) Mapping climate vulnerability and poverty in Africa. Report to the Department for International Development, ILRI, Nairobi, Kenya. p 200

You L, Wood S, Wood-Sichra U (2009) Generating plausible crop distribution maps for Sub-Saharan Africa using a spatially disaggregated data fusion and optimization approach. Agric Syst 99(2-3):126-140

Zemmelink G, Romney D (1999) "Dairy farming in Kenya: resource utilization and N-flows." Paper presented at the 10th International Symposium on Outcome and Perspectives of Collaborative Research, Faculty of Veterinary Medicine, De Uithof, Utrecht, Netherlands, November 5 